\title{
Isolation of Acinetobacter calcoaceticus BP-2 Capable of Degradation of Bisphenol A
}

\author{
Gi-Seok Kwon ${ }^{1}$, Dong-Geol Kim ${ }^{1,2}$, Jung-Bok Lee ${ }^{1}$, Kee-Sun Shin ${ }^{3}$, Eun-Joo Kum ${ }^{4}$ and Ho-Yong \\ Sohn ${ }^{4, *}$
}

${ }^{1}$ The School of Bioresource Sciences, Andong National University, Andong 760-749, Korea

${ }^{2}$ Kolmar Korea R\&D Center, Yeongi, Chung-Nam 339-851, Korea

${ }^{3}$ Biological Resource Center, Korea Research Institute of Bioscience and Biotechnology, Daejeon 305-600, South Korea

${ }^{4}$ Department of Food and Nutrition, Andong National University, Andong 760-749, Korea

Received August 29, 2006 / Accepted October 11, 2006

\begin{abstract}
Bisphenol A (BPA), 2,2-bis(4-hydroxyphenyl)propane, has been widely used as a monomer for production of epoxy resins and polycarbonate plastics, and final products of BPA include adhesives, protective coatings, paints, optical lens, building materials, compact disks and other electrical parts. Since BPA is a toxic chemical to elicit acute cell cytotoxicity and chronic endocrine disrupting activity, the degradation of BPA has been focused during last decades. To overcome the problem of photo-, and chemical-degradation of BPA, in this study, a bacterium that is able to biodegrade BPA, was isolated. The bacterium, isolated from the soil of plastic factory, was identified as Acinetobacter calcoaceticus (strain BP-2) based on physiological and $16 \mathrm{~S}$ rDNA sequencing analysis. A. calcoaceticus BP-2 was able to grow in the presence of $1140 \mu \mathrm{g} \mathrm{ml}^{-1} \mathrm{BPA}$. Biodegradation experiments showed that BP-2 mineralized BPA via 4-hydroxybenzoic acid and 4-hydroxyacetophenone, and average degradation rate was $53.3 \mu \mathrm{g} \mathrm{ml}^{-1}$ day ${ }^{-1}$ under optimal conditions $\left(\mathrm{pH} 7\right.$ and $30^{\circ} \mathrm{C}$ ). In high density resting cell ( $3.5 \mathrm{~g}$-dcw..$^{-1}$ ) experiments, the maximal degradation rate was increased to $89.7 \mathrm{\mu g} \mathrm{ml}^{-1} \mathrm{~h}^{-1}$. Our results suggest that BP-2 has high potential as a catalyst for practical BPA bioremediation.
\end{abstract}

Key words - Acinetobacter calcoaceticus BP-2, biodegradation, bisphenol A, detoxification

\section{Introduction}

BPA has been widely used as a monomer for the production of epoxy resins and polycarbonate plastics, and as a stabilizer for various types of plastics[1]. The annual production of BPA exceeds 640,000 metric tons in worldwide[19], and about $0.1 \%$ of produced BPA $(653$ tons/year) releases environment[18]. BPA may be released from canned foods, a drinking water-tank and dental sealants, and inadvertently released as fugitive dust emissions during manufacturing, handling and processing[13]. Previous reports demonstrated that BPA causes extensive damage to various organ systems via oxidative stress[2], and acts as anti-androgenic and anti-estrogenic chemical at concentrations as low as $2 \sim 5 \mu \mathrm{g}$ $1^{-1}[3,16]$. The chlorination of BPA in aqueous media resulted in the formation of more toxic and persistent chlorinated products, such as 2-chlorobisphenol A, 2,2'-dichlorobisphenol A, or 2,2',6-trichlorobisphenol A[21].

*Corresponding author

Tel : +82-54-820-5491, Fax : +82-54-823-1625

E-mail : hysohn@andong.ac.kr
Photodegradation of BPA into glycerol or 2-hydroxy propanoic acid was intensively studied, but the by-products, such as 4-isopropylphenol, phenol and a semiquinone derivative of bisphenol $A$, were still toxic[5,14,18]. Biodegradation is alternative method for BPA detoxification, because the degradation products of biodegradation, such as 4-hydroxybenzoic acid and 4-hydroxyacetophenone, had no apparent toxicity and mutagenic activity[6,12,14]. Moreover, biodegradation is more efficient and rapid compared than the photodegradation $[8,12,17,18]$. Different algae[4], a gram negative bacterium[12], and Streptomyces sp. [9] were isolated potent BPA degraders and the majority of biodegradation research used $25 \sim 50 \mu \mathrm{g} \mathrm{ml}^{-1}$ of BPA as test concentrations $[7,8,10,19]$. Considering the low volatility and high solubility of BPA $\left(300 \mathrm{\mu g} \mathrm{ml}^{-1}\right.$ at $\mathrm{pH} 7$ ) in water and rapid migration to water from different products at room temperature[18,20], it is worth studying the biodegradation of BPA at concentration above $300 \mathrm{\mu g}$ $\mathrm{ml}^{-1}$. In fact, intensive accumulation of BPA and tetrabromobisphenol $\mathrm{A}$, as high as $450 \mu \mathrm{g} \mathrm{ml}^{-1}$, in soil were reported recently[14].

In this work, we isolated a bacterium to efficiently de- 
grade BPA from BPA-polluted soil samples using mineral salt medium containing $500 \mu \mathrm{g} \mathrm{ml}^{-1}$ of BPA as sole carbon source for practical bioremediation. The results presented here suggest that the newly selected bacterium has a potential for BPA degradation.

\section{Materials and Methods}

\section{Media and chemicals}

BPA, 4-hydroxybenzoic acid (4-HBA) and 4-hydroxyacetophenone (4-HAP) were purchased from Aldrich Chemical Co. (Milwaukee, USA). Ethylacetate for BPA extraction and acetonitrile for HPLC analysis were purchased from Junsei Chemical Co. (Tokyo, Japan). The liquid mineral salt medium (MSM) used contained $1 \mathrm{~g} \mathrm{NH}_{4} \mathrm{NO}_{3}, 1 \mathrm{~g}$ $\mathrm{K}_{2} \mathrm{HPO}_{4}, 0.5 \mathrm{~g} \mathrm{MgSO}_{4} \cdot 7 \mathrm{H}_{2} \mathrm{O}, 0.2 \mathrm{~g} \mathrm{CaCO}$ per liter of distilled water $(\mathrm{pH} 7.0)$. For solid medium, $1.5 \%(\mathrm{w} / \mathrm{v})$ Bacto agar (Difco, Detroit, USA) was added to the liquid MSM. BPA was dissolved in DMSO at concentration of $30 \mathrm{~g} \mathrm{l}^{-1}$ and added to the medium as appropriate concentration after sterilization.

\section{Isolation of BPA degraders}

About two grams of soil samples, which were collected from BPA applied field and plastic factory in Kyeongsan, Kyungpook, Korea, were put into $250 \mathrm{ml}$ erlenmeyer flask containing $50 \mathrm{ml}$ liquid MSM with $500 \mathrm{\mu g} \mathrm{ml}^{-1} \mathrm{BPA}$, and the cultures were incubated at $30^{\circ} \mathrm{C}$ with shaking (130 rpm). After 7 days incubation, two milliliters of individual flask culture were transferred to $50 \mathrm{ml}$ BPA-MSM and further cultured for 7 days at $30^{\circ} \mathrm{C}$. Then, culture broth was applied to solid MSM containing $500 \mu \mathrm{g} \mathrm{ml}^{-1}$ BPA for isolating single colonies.

Assay of BPA and its metabolites, and total organic carbon (TOC)

The isolated bacteria were incubated in BPA-MSM for 7 days at $30^{\circ} \mathrm{C}$ in a rotary shaker $(130 \mathrm{rpm})$. And then, the total culture broth was extracted twice with ethylacetate to prevent extraction errors. After concentration with nitrogen gas, BPA and its metabolites in the extract were determined by a HPLC system; SCL-10A system controller, LC-10AD pump and SPD-10A UV detector, Shimadzu, Japan, Nova-Pak $\mathrm{C}_{18}$ column (Waters, USA), the eluent of $70 \%$ acetonitrile $(\mathrm{v} / \mathrm{v})$, the flow rate of $1 \mathrm{ml} \mathrm{min}^{-1}$, the injection volume of $10 \mu \mathrm{l}$ and the detection at $254 \mathrm{~nm}$.
Retention time for BPA, 4-HBA and 4-HAP were 13.04, 1.78 and $2.45 \mathrm{~min}$ under these analytical conditions, respectively. To confirm BPA utilization by the isolated strain, the organic carbon concentrations in the biomass and in the culture, and the $\mathrm{CO}_{2}$ concentrations in the culture and headspace of culture, were measured using a TOC-500 analyzer as previously reported[12]

\section{Identification of BPA degrader}

To identify the isolated bacterium, physiological test based on a Bergey's manual and 165 rDNA sequence analysis were used. For sequence analysis, the same instrumentation and analytical techniques were used as previously reported[11,22]. The $16 \mathrm{~S}$ partial sequence (493 bp) of strain BP-2 was deposited in the GenBank database under accession number AF458218.

\section{Degradation of BPA by $A$. calcoaceticus BP-2}

Isolated strains were culture in a BPA-MSM, collected by centrifugation, and washed twice in $15 \mathrm{mM}$ phosphate buffer ( $\mathrm{pH} \mathrm{7.0)}$. The washed cells were inoculated into the MSM containing $303 \mu \mathrm{g} \mathrm{ml}^{-1}$ of BPA, which adjusted to an optical density of 0.1 at $550 \mathrm{~nm}$. Degradation was conducted at $30^{\circ} \mathrm{C}$ in a rotary shaker $(130 \mathrm{rpm})$ for 7 days, and $\mathrm{BPA}$, its metabolites, culture $\mathrm{pH}$, and biomass were determined at $24 \mathrm{~h}$ intervals. To evaluate physical loss or non-biological degradation, such as non-specific adsorption by the cell components, volatile loss and/or chemical degradation of $\mathrm{BPA}$, the experiments were repeated with heat-killed cells or without inoculation. For high density resting cell biodegradation, cells were collected, washed twice in $15 \mathrm{mM}$ phosphate buffer $(\mathrm{pH} \mathrm{7.0)}$ and cultured for $24 \mathrm{~h}$ at $30^{\circ} \mathrm{C}$ in a rotary shaker using the same buffer to obtain maximum BPA degradation activity and cell growth. The starved cells were inoculated into $100 \mathrm{ml}$ erlenmeyer flask containing $20 \mathrm{ml}$ of phosphate buffer (15 $\mathrm{mM}, \mathrm{pH} \mathrm{7.0)}$ with $303 \mu \mathrm{g} \mathrm{m}^{-1}$ of BPA, which adjusted to optical density of 2.0 at $550 \mathrm{~nm}$ or dry cell weight of 3.5 g. $1^{-1}$. Degradation of BPA was conducted at $30^{\circ} \mathrm{C}$ in a rotary shaker (130 rpm) for $12 \mathrm{~h}$ and BPA and its: metabolites were measured at $3 \mathrm{~h}$ intervals.

\section{Results and Discussion}

Screening of BPA degrader and identification of strain BP-2 
From 30 BPA-polluted soil samples, about 80 bacteria were isolated using solid.MSM containing $500 \mu \mathrm{g} \mathrm{ml}^{-3}$ of BPA. Biodegradabilities of isolated bacteria were evaluated

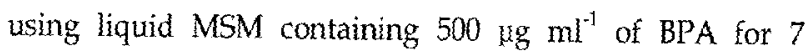
days (data not shown), and 4 bacteria among them, strain BP-2, BP-5, BP-13 and BP-21, showed high degradation activities (the degradation ratios of strain BP-2, BP-5, BP-13 and $B P-21$ were $92 \%, 68 \%, 79 \%$ and $69 \%$, respectively), and strain BP-2 exhibiting the highest activity was finally selected for the further study. No growth was observed when BPA was omitted from the MSM media and $\mathrm{pH}$ stayed constant at -7.2 , indicating that strain BP-2 could not grow with DMSO. Without inoculation of strain BP-2, no decrease of BPA was observed, suggesting that losses due to volatility or non-biological degradation were not important under the culture conditions employed. The finally selected BP-2 was able to grow in the presence of $1140 \mathrm{~kg}$ $\mathrm{ml}^{.3}$ BPA (result not shown).

Strain BP-2 was gram-negative, oxidase test-negative, and urea test-negative bacteria. Analysis of a Vitek Gram-Negative Identification ( + ) Kit showed similarity of $95 \%$ to Acinetobacter sp. Further, a 493-base segment of the $16 \mathrm{~S}$ rDNA [AF458218 in GenBank(http//www.ncbinlm. nih.gov/entrez/II showed similarity of $99 \%$ to that of Acinetobacter calcoaceticus. From these results, strain BP-2 was identified as $A$. calconceticus. Although many bacteria capable of degrading BPA were reported[4,6,7-9,14], A. calcoaceticus as a BPA degrader has not been reported until now:

\section{BPA degradation by $A$. calcoaceticus BP-2}

Total carbon analysis during $\mathrm{BPA}$ degradation at $\mathrm{pH} 70$ and $30^{\circ} \mathrm{C}$ demonstrated that $72.2 \%$ of BPA added $218.7 \mathrm{\mu g}$ $\mathrm{ml}^{-2}$ of $\left.303 \mu \mathrm{g} \mathrm{mi}\right)$ was converted to biomass $(140.98 \mathrm{\mu g}$ $\left.\mathrm{ml}^{-1}\right)$ and $\mathrm{CO}_{2}\left(77.75 \mu \mathrm{gl}^{-3}\right)$. The remained soluble organic carbon (BPA) in the culture was $17.8 \%\left(53.9 \mu \mathrm{g} \mathrm{ml^{-1 }}\right)$. These results further suggest that the decrease of $\mathrm{BPA}$ in the culture is due to the mineralization and assimilation of BPA by the A. calcoaceticus BP-2.

To characterize the BPA degradation by $A$. calcoaceticus $B P-2$, the degradation activity was measured at different initial $\mathrm{pHs}$ and culture temperatures using MSM containing $303 \mathrm{ug} \mathrm{m}^{-1}$ of BPA. As shown in Fig. 1, maximum degradation activity was observed at $\mathrm{pH} 7,0$ and $30^{\circ} \mathrm{C}$, respectively (the degradation ratios were above $93.5 \%$ ). The cell growth showed a good correlation with BPA degrada-
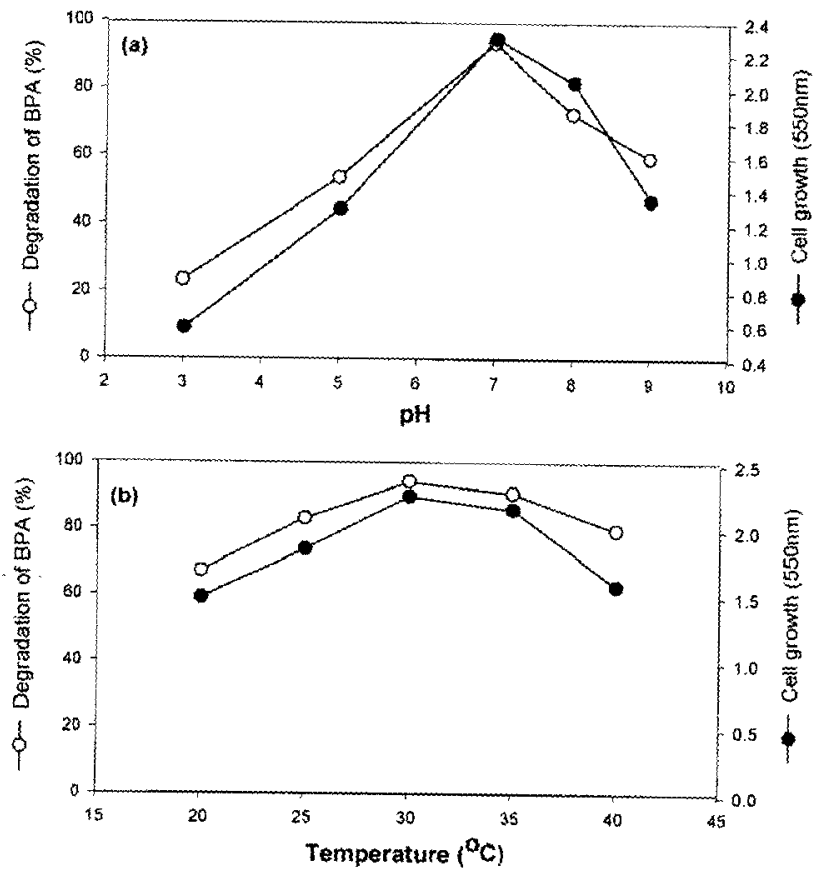

Fig. 1. Effect of culture $\mathrm{pH}$ (a) and temperature (b) on BPA degradation and cell growth of A calcoaceticus BP-2. The initial concentration of $B P A$ in the mineral salt medium was adjusted to $303 \mathrm{ug} \mathrm{m}^{-7}$. After 7 days cultivation, the cell growth and remained BPA were determined.

tion activity. Although maximum degradation activity was shown at $30^{\circ} \mathrm{C}$, the strain $\mathrm{BP}-2$ had a potent BPA degradation activity at temperature ranges of $20 \sim 40^{\circ} \mathrm{C}$. The growths and degradation activities were severely de creased at $\mathrm{pH} 5$ and $\mathrm{pH} 3$, suggested that the $\mathrm{BP}-2$ needs adjustment of $\mathrm{pH}$ to neutral before $\mathrm{BPA}$ degradation.

Under optimum culture conditions, the growth of $A$. calcoaceticus BP-2 reached a maximum at 5 days and afterwards decreased in some degree (Fig, 2a). The culture $\mathrm{pH}$ decreased from 7.0 to 5.6 as cell growth. After 5 days, the $\mathrm{pH}$ was slightly increased inversely proportional to cell growth. The BPA concentration in culture decreased continuously with concomitant to cell growth; the final concentration of BPA was less than $15 \mu \mathrm{g} \mathrm{ml}^{-1}$ and the average degradation rate during 5 day cultivation was $53.3 \mu \mathrm{g} \mathrm{ml^{-1 }}$ day $^{-2}$ (Fig. 2b). 4-HBA, as a reported non-toxic metabolite[12,14], was identified during BPA degradation. The maximum concentration, $15.99 \mathrm{jg} \mathrm{ml^{-1 }}$, was found at 6 day and the average accumulation rate was $2.66 \mathrm{ug} \mathrm{m}^{-1} \mathrm{day}^{-1}$. 4-HAP, another reported non-toxic metabolite, was detected after 2 day, and the maximum concentration was 0.34 ug m $\mathrm{m}^{-1}$. These results are agreement with previous re- 


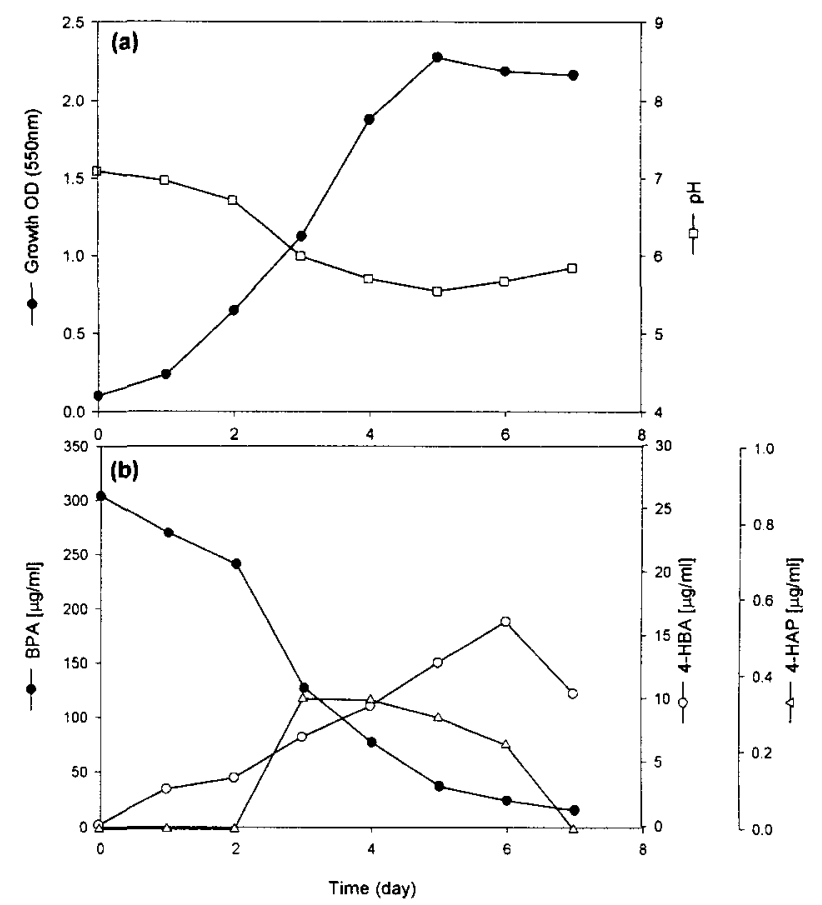

Fig. 2. Biodegradation of BPA by A. calcoaceticus BP-2. (a) Growth of $A$. calcoaceticus BP-2 (O) and culture $\mathrm{pH}$ $(\square)$ in MSM containing $303 \mu \mathrm{g}-\mathrm{BPA} \mathrm{m} \mathrm{l}^{-1}$ during 7 days cultivation at initial $\mathrm{pH} 7$ and $30^{\circ} \mathrm{C}$ with shaking (130 rpm). (b) Degradation of BPA (O) and production of 4-HBA $(O)$ and 4-HAP $(\triangle)$ in BPA-MSM.

ports that gram-negative bacteria MV1 and WH1 mineralize BPA via 4-HBA or 4-HAP[14,20]. After 6 day, when the concentration of BPA decreased below $24 \mu \mathrm{g} \mathrm{ml}^{-1}$, the concentration of 4-HBA and 4-HAP were rapidly decreased, suggesting that 4-HBA and 4-HAP also degraded and mineralized. These results suggest that $A$. calcoaceticus BP-2 mineralize and assimilate BPA via mainly 4-HBA and 4-HAP as non-toxic metabolites and $A$. calcoaceticus BP-2 has high potential for practical application in BPA bioremediation.

\section{BPA degradation by high density resting cell}

Since the degradation rate of BPA is proportionally related to cell concentration, the rapid degradation using high density resting cell was investigated. As shown in Fig. 3, the BPA in phosphate buffer was rapidly decreased from $303 \mu \mathrm{g} \mathrm{ml}^{-1}$ to $13.5 \mu \mathrm{g} \mathrm{ml}^{-1}$ by high density resting cell (3.5 g-dcw. $\mathrm{I}^{-1}$ ) during $12 \mathrm{~h}$ incubation. Without cell inoculation, the BPA concentration did not show apparent changes. During first $3 \mathrm{~h}$ incubation, about $89 \%$ of BPA was degraded and the maximum degradation rate was $89.7 \mu \mathrm{g}$

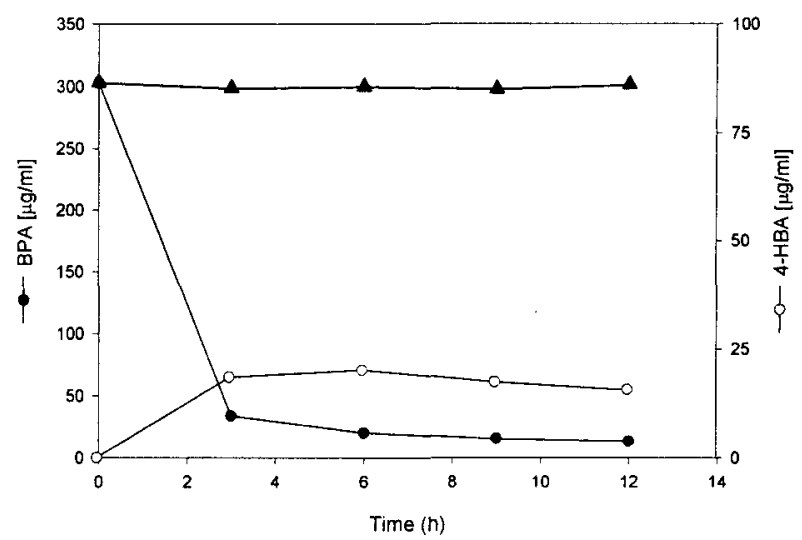

Fig, 3. Biodegradation of BPA by high density resting cells of A. calcoaceticus BP-2. Concentration of BPA (O) and 4-HBA (O) with inoculation of resting cells, and BPA (A) concentration without inoculation of cells in 15 $\mathrm{mM}$ phosphate buffer ( $\mathrm{pH}$ 7.0) containing $303 \mu \mathrm{g}$ $\mathrm{ml}^{-1}$ BPA. Cells were cultured in a BPA-MSM, collected, washed twice in $15 \mathrm{mM}$ phosphate buffer $(\mathrm{pH} \mathrm{7.0)}$ and starved for $24 \mathrm{~h}$ at $30^{\circ} \mathrm{C}$ in a rotary shaker (130 rpm) using the same buffer. The starved cells were inoculated which adjusted to optical density of 2.0 at 550 $\mathrm{nm}\left(3.5 \mathrm{~g}\right.$-dcw. $\left.\mathrm{l}^{-1}\right)$.

$\mathrm{ml}^{-1} \mathrm{~h}^{-1}$. In metabolites analysis, only 4-HBA was detected. Its concentration rapidly increased to $18.5 \mathrm{\mu g} \mathrm{ml}^{-1}$ at $3 \mathrm{~h}$ and maintained without apparent changes for $12 \mathrm{~h}$. These results suggest that $A$. calcoaceticus BP-2 could successfully apply to high cell density-rapid degradation of BPA under environmental conditions.

The rapid degradation of $\mathrm{BPA}$ is important in treatment of drinking water. Because, BPA is easily chlorinated with residual chlorine in the water, that has been added as a disinfectant, and transformed to more toxic and recalcitrant chlorinated BPAs, such as 2,2',6,6' $6^{\prime}$-tetrachlorobisphenol A, 2,6-dichlorobisphenol $\mathrm{A}$, and 2,2',6-trichlorobisphenol A $[15,21]$. Therefore, rapid BPA degradation before chlorination in water may have advantages in public health. The maintaining of high cell density is not easy for practical application. The high cell density immobilization of strain BP-2 and application of plug flow type reactor against chlorinated- or non- chlorinated water are under way in our laboratory. For practical application of BP-2, in wastewater or soils, further studies on interactions between indigenous microflora and A. calcoaceticus BP-2, and on maintaining of degradation activity at broad $\mathrm{pH}$ are necessary. 


\section{Acknowledgements}

This work was supported by a grant from BioGreen21 program, Rural Development Administration, Republic of Korea (200503010344210060200).

\section{References}

1. Ash, M., and I. Ash. 1995. Handbook of plastic and rubber additives. Grower, Hampshire, UK.

2. Atkinson, A., and D. Roy. 1995. In vitro conversion of environmental estrogenic chemical bisphenol-A to DNA binding metabolite(s). Biochem. Biophys. Res. Commun. 210, 424-433.

3. Chen, M.-Y., M. Ike, and M. Fujita. 2002. Acute toxicity, mutagenicity, and estrogenicity of bisphenol-A and other bisphenols. Environ.Toxicol. 17, 80-86.

4. Hirooka, T., Y. Akiyama, N. Tsuji, T. Nakamura, H. Nagase, K. Hirata, and K. Miyamoto. 2003. Removal of hazardous phenols by microalgae under photoautotrophic conditions. J. Biosci. Bioeng. 95, 200-203.

5. Howard, P. H. 1989. Handbook of Environmental Fate and Exposure Data, vol. 1. Lewis Publisher, Chelsea, MI.

6. Ike, M., M.-Y. Chen, C.-S. Jin, and M. Fujita. 2002. Acute toxicity, mutagenicity, and estrogenicity of biodegradation products of bisphenol-A. Environ. Toxicol. 17, 457-461.

7. Kang, J.-H., and F. Kondo. 2002. Bisphenol A degradation by bacteria isolated from river water. Arch. Environ. Contam. Toxicol. 43, 265-269.

8. Kang, J.-H., and F. Kondo. 2002. Effects of bacterial counts and temperature on the biodegradation of bisphenol $\mathrm{A}$ in river water. Chemosphere 49, 493-498.

9. Kang J.-H., N. Ri, and F. Kondo. 2004. Streptomyces sp. strain isolated from river water has high bisphenol A degradability. Lett. Appl. Microbiol. 39, 178-180.

10. Klecka, G. M., S. J. Gonsior, R. J. West, P. A. Goodwin, and D. A. Markham. 2001. Biodegradation of bisphenol A in aquatic environments: river die-away. Environ. Toxicol. Chem. 20, 2725-2735.

11. Kwon, G.S., J. E. Kim, T. K. Kim, H. Y. Sohn, S. C. Koh, K.-S. Shin, and D.G. Kim. 2002. Klebsiella pneumonia KE-1 degrades endosulfan without formation of the toxic me- tabolites, endosulfan sulfate. FEMS Lett. 215. 255-259.

12. Lobos, J. H., T. K. Lein, and T. M. Su. 1992. Biodegradation of bispehnol $\mathrm{A}$ and other bisphenols by a gram-negative aerobic bacterium. Appl. Environ. Microbiol. 58, 1823-1831.

13. Olea, N., R. Pulgar, P. Perez, M. F. Olea-Serrano, A. Rivas, A. Novillo-Fertrell, V. Pedraza, A. M. Soto, and C. Sonnenschein. 1996. Estrogenicity of resin-based composites and sealants used in dentistry. Environ. Health Persp. 104, 298-305.

14. Ronen, Z., and A. Abeliovich. 2000. Anaerobic-aerobic process for microbial degradation of tetrabromobisphenol A. Appl. Environ. Microbiol. 66, 2372-2377.

15. Ryoko, K. N., T. Yoshiyasu, and N. Ryushi. 2002. Identification of estrogenic activity of chlorinated bisphenol A using a GFP expression system. Environ. Toxicol. Pharmacol. 12, 27-35.

16. Samuelsen, M., C. Olsen, J. A. Holme, E. Meussen-Elholm, A. Bergmann, and J. K. Hongslo. 2001. Estrogen-like properties of brominated analogs of bisphenol A in the MCF-7 human breast cancer cell line. Cell Biol. Toxicol.17,139-151.

17. Spivack, J., T. K. Leib, and J. H. Lobos. 1994. Novel pathway for bacterial metabolism of Bisphenol A. J.Biol.Chem. 269, 7323-7329.

18. Staples, C. A., P. B. Dorn, G. M. Klecka, S. T. O'Block, and L. R. Harris. 1998. A review of the environmental fate, effects, and exposures of bisphenol A. Chemosphere 36, 2149-2173.

19. West, R. J., P. A. Goodwin, and G. M. Klecka. 2001. Assessment of the ready biodegradability of bisphenol A. Bull. Environ. Contam. Toxicol. 67, 106-112.

20. Yamamoto, T., and A. Yasuhara. 2000. Determination of bisphenol A migrated from polyvinyl chloride hoses by GC/MS. Bunseki Kagaku 49, 443-447.

21. Yamamoto, T. and A. Yashuhara. 2002. Chlorination of bisphenol $\mathrm{A}$ in aqueous media: formation of chlorinated bisphenol A congeners and degradation to chlorinated phenolic compounds. Chemosphere 46, 1215-1223.

22. Yoon, J. H., S. T. Lee, S. B. Kim, W. Y. Kim, M. Goodfellow, and Y. H. Park. 1997. Restriction fragment length polymorphism analysis of PCR-amplified 165 ribosomal DNA for rapid identification of Saccharomonospora strains. Int. J. Syst. Bacteriol. 47, 111-114. 


\section{초록 : Bisphenol A 분해균주 Acinetobacter calcoaceticus BP-2의 분리 및 bisphenol A 분해 특성}

권기석 ${ }^{1} \cdot$ 김동걸 $^{1,2} \cdot$ 이중복 ${ }^{1} \cdot$ 신기선 $^{3} \cdot$ 금은주 $^{4} \cdot$ 손호용 ${ }^{4 *}$

( ${ }^{1}$ 안동대학교. 생명자원과학부, ${ }^{2}$ 한국콜마 중앙연구소, ${ }^{3}$ 한국생명공학연구원, ${ }^{4}$ 안동대학교 식품영양학과)

$\mathrm{BPA}$ 는 에폭시 수지 및 플라스틱 생산의 단량체로서 사용되어 왔으며, 접착제, 페인트, 광학렌즈, 건축자재, 전 자제품 소재 등 다양한 제품을 생산하는 데 사용되고 있다. 그러나 BPA의 급성세포독성 및 내분비교란활성이 보고되면서 BPA의 분해에 대한 연구가 집중되고 있다. 본 연구에서는 $\mathrm{BPA}$ 의 광분해 및 화학적 분해의 문제점을 극복하고, 실제적 BPA의 생물학적 분해를 목표로 BPA 분해균을 플라스틱 공장의 토양으로부터 분리하였다. 분 리균주 중 가장 활성이 우수한 BP-2는 $5 \mathrm{mM}$ 의 BPA처리에서 성장할 수 있었으며, $\mathrm{pH} 7,30^{\circ} \mathrm{C}$ 의 최적 배양조건에 서 $53.3 \mathrm{ug} \mathrm{ml}^{-1} \mathrm{day}^{-1}$ 의 분해속도를 나타내었다. 균주 동정결과 BP-2는 Acinetobacter calcoaceticus로 확인되었으 며, $3.5 \mathrm{~g}$-건조중량 $\mathrm{l}^{-1}$ 의 고농도 휴식 세포 반응 결과 $89.7 \mathrm{\mu g} \mathrm{ml}^{-1} \mathrm{~h}^{-1}$ 의 BPA 분해속도를 나타내었다. 이러한 결과 는 고농도 세포농도를 유지하는 경우, BP-2 균주가 실제적 BPA분해를 위한 생물촉매로 사용될 수 있음을 제시하 고 있다. 